\title{
CARNAVAL FINANCEIRO: \\ CONTAS "MAQUIADAS" NÃO VÃO \\ TORNAR NOSSO PAÍS MAIS BONITO
}

Coluna publicada em 12.2.2013: <http://www.conjur.com.br/2013-fev-12/ contas-vista-contas-maquiadas-nao-tornar-nosso-pais-bonito $>$

Hoje é carnaval, dia da festa que fez do Brasil um dos países mais conhecidos do mundo. Certamente não é o dia ideal para falar de Direito Financeiro, mas hoje é dia da coluna, e vamos a ela.

O Brasil é país afamado no mundo todo por várias coisas boas, entre elas nosso carnaval, o mais bonito do planeta. Mas como nem tudo são festas e flores, outras coisas não tão boas nos tornaram conhecidos, como a reputação de sermos "o país do jeitinho"...

Característica esta que voltou à tona recentemente, em razão de críticas à ação de nossos governantes, recentemente publicada no importante periódico Financial Times, referindo-se a medidas tomadas pelo governo federal na contabilização de nossas finanças públicas.

A contabilidade pública, ${ }^{1}$ e também a contabilidade nacional, ${ }^{2}$ em um país de dimensões continentais como o nosso, com uma economia que cresce e já está entre as maiores do mundo, não é simples. Sejamos claros: é complexa. Extremamente complexa.

Apenas para se ter uma ideia, o orçamento federal, que contém a previsão de receitas e despesas da administração pública federal para o exercício em curso (2013), tem previsão de arrecadação e gasto no montante de incríveis $\mathrm{R}$ \$2.250.868.084.933,00

1 Basicamente voltada à quantificação das receitas e despesas orçamentárias dos entes governamentais sob uma perspectiva microeconômica.

2 Que se ocupa fundamentalmente da quantificação dos grandes agregados da Economia, como o PIB, sob uma perspectiva macroeconômica. 
(dois trilhões, duzentos e cinquenta bilhões, oitocentos e sessenta e oito milhões, oitenta e quatro mil, novecentos e trinta e três reais), conforme projeto de lei orçamentária apresentado (art. 10), e ainda não aprovado (mas que, de certa forma, já está em vigor, vide coluna de 15 de janeiro de 2013, E o ano começa sem a aprovação do orçamento federal; afinal de contas, para tudo tem um jeitinho...).

E isso representa apenas uma parcela do dinheiro em circulação no país, pois se refere ao setor público, e tão somente a uma parte dele, haja vista que temos ainda todos os estados-membros de nossa federação e os mais de cinco mil municípios, que não estão incluídos nessa conta.

Esse orçamento deve detalhar minuciosamente onde será aplicado cada centavo desses trilhôes de reais, especificando cada despesa em seus diversos demonstrativos, mostrando da forma mais exata e precisa possível o que, como, quem e para que será utilizado. É evidente que a contabilidade pública exige técnicas sofisticadas e complexas para organizar esses números. Não é diferente a situação da contabilidade nacional ao calcular o PIB e outros indicadores das contas nacionais.

E esses dados são importantes, pois deles dependem as ações dos governantes, que devem tomar as decisões sobre os rumos do país, bem como as ações de todos os agentes econômicos, que precisam de dados precisos e confiáveis para também definir investimentos e os rumos de seus negócios.

Daí a importância de uma contabilização que seja a mais técnica, confiável e transparente possível.

Desde a estabilização da moeda e o aumento no rigor das normas sobre finanças públicas, especialmente a partir da Lei de Responsabilidade Fiscal, a contabilização das informações econômicas aumentou substancialmente sua importância, pois passou a produzir dados de extrema relevância para a condução das políticas governamentais e consequente indicação dos rumos do país para o setor público e privado, nacional e estrangeiro.

As restrições fiscais impostas pelas novas normas, associadas ao rigor da legislação, que contém sanções por vezes bastante severas para o seu descumprimento, bem como a crescente busca por maior transparência, acabaram por intensificar o uso da chamada "contabilidade criativa" no setor público. Na ânsia de cumprir as normas de finanças públicas, ainda que os números não sejam favoráveis, por vezes indicando em sentido oposto ao que se pretende, os operadores da contabilidade pública passaram a se aproveitar das brechas da lei, divergências na interpretação dos textos normativos, lacunas, flexibilidades e toda sorte de possibilidades, para "ajustar" os números aos interesses dos governantes, de modo a "fazer de conta" que os resultados foram alcançados tal como planejados. O que, constata-se, não é 
de grande dificuldade quando se trata de números gigantescos, como se exemplificou há pouco.

E foi por meio da utilização dessas "técnicas de contabilidade criativa" que transcorreram os fatos ora mencionados, que agora podem ser mais bem compreendidos.

No sistema de planejamento da ação governamental brasileiro compete à Lei de Diretrizes Orçamentárias estabelecer as metas e prioridades da administração pública federal para o exercício financeiro subsequente (CF, art. $165, \$ 2^{\circ}$ ), o que foi feito na LDO da União para 2013 (Lei Federal 12.708, de 17.8.2012), em seu artigo $2^{\circ}$, em que está prevista a meta de superávit primário ${ }^{3}$ para o setor público no montante de praticamente $\mathrm{R} \$ 156$ bilhões.

Vislumbrada a impossibilidade de cumprir a meta, realizaram-se, segundo as informaçôes divulgadas pela imprensa, uma série de manobras contábeis, com a realocação de recursos entre as diversas rubricas orçamentárias, bem como operações contábeis e financeiras, ${ }^{4}$ de modo a fazer constar nos demonstrativos orçamentários o cumprimento da meta. Utilização de empresas públicas, bancos públicos de fomento, recursos do recém-criado Fundo Soberano, e até pedido para postergar aumento de preços de passagens de ônibus. Um verdadeiro arsenal de medidas paliativas que não resolvem o problema de fundo, mas apenas tentam contornar, adiar e alterar dados que não interessam ao governo divulgar.

Fato que chegou ao conhecimento público, especialmente a partir da divulgação, pelo Financial Times, do "Brazil's monetary jeitinho", denunciando as diversas medidas tomadas pelo governo com a finalidade de ajustar dados de crescimento do PIB, controle de inflação, cumprimento de metas de superávit e outras voltadas a "maquiar" os números da economia brasileira, de modo a torná-los mais palatáveis perante o mercado financeiro internacional.

Medidas como essa comprometem um dos mais - se não o mais - importante "ativo" de um país, que é sua credibilidade. Mais do que isso, a divulgação de informaçōes imprecisas afronta o princípio da publicidade da administração pública, claramente expresso no artigo 37 de nossa Constituição. E o da transparência fiscal, que os artigos 48 e 49 da Lei de Responsabilidade Fiscal ${ }^{5}$ se esmeraram em especificar de modo preciso, detalhando a forma e os meios de divulgação de todos

3 Cujo conceito já não é nada simples para quem não é especialista no assunto. Basicamente consiste no resultado nominal positivo menos os juros nominais incidentes sobre a dívida líquida interna e externa.

4 Não sendo o caso de entrar em detalhes, até pela complexidade técnica envolvida.

5 E cuja redação foi recentemente aperfeiçoada pela Lei Complementar 131, de 27.5.2009. 
os demonstrativos e relatórios orçamentários e financeiros, tudo para tornar essas informações públicas, transparentes e confiáveis.

Todo esse esforço pode se tornar inútil com a concretização dessas manobras contábeis, pondo a perder, num único ato, a credibilidade que levou anos, talvez décadas, para ser construída, e poderá levar outro tanto para ser recuperada.

O Brasil já tem um lindo carnaval, e nele podem ser vistas as mais belas mulheres, o mundo todo sabe disso. Não precisamos embelezar nossos números, não serão algumas contas "maquiadas" que vão tornar nosso país mais bonito.

Deixemos a maquiagem para as nossas passistas, e não vamos permitir que essa "dança dos números" se transforme no "samba do crioulo doido"...

E um excelente carnaval a todos! 